\title{
Training mode of information class talents in Local Undergraduate Colleges
}

\author{
Jian Peng, Jing-guo Dai, Hui-yong Yuan, \\ College of information science and engineering, Shaoguan University \\ Shaoguan Guangdong, China
}

\begin{abstract}
Analyzes the local undergraduate colleges and universities information class reality problems of talent training, put forward in combination with the practical situation of schools, to carry out the cooperation between colleges and industry cooperation, joint personnel training mode, oriented to the market demand, and actively coordinate to solve all kinds of problems.
\end{abstract}

Keywords-information class; training mode; local Undergraduate College

\section{INTRODUCTION}

In recent years, the employment survey shows that $48.8 \%$ of the students in computer science graduates are trained to work through social training institutions, including a number of "985" universities, in the application of students' skills training to the social training institutions, higher education graduates in the community is only a preliminary processing of semifinished products. To explore the training mode of computer professional talents, to market oriented, to promote the cooperation between enterprises and enterprises, to cultivate the market needs of the computer professional application oriented talents to become the subject of [1].

\section{ABILITY TO GIVE PRIORITY TO}

Influenced by the traditional management mode and management concept, our country's higher education has always been "the ivory tower mode of" state ownership, high concentration, plan control, administrative intervention ". Along with the development of the socialist market economy, modern higher education is facing many new problems. In spite of the experience of the developed countries, the higher education is the ideal, but the market orientation will be the vitality of the development of higher education.

In order to cultivate the applied undergraduate talents in local undergraduate colleges and universities, it has been influenced by the traditional undergraduate education ideas. Take the computer as an example, the general undergraduate computer major is to cultivate a good scientific literacy, to master computer hardware, software and application of basic knowledge and basic skills, can be engaged in computer teaching, scientific research and management of advanced computer technology personnel; its course is also the computer science system, focusing on the system, academic, research institutes, research and development department. Application oriented computer science is focused on engineering technology application skills and innovation ability training, focusing on technical post, technology application, technology engineering practice, mainly for technology intensive enterprises, institutions of information technology research and development of ${ }^{[2]}$.

\section{THE COOPERATION BETWEEN COLLEGES AND INDUSTRY COOPERATION, JOINT TRAINING}

Applied undergraduate colleges and universities computer Science College can choose the professional and strong enterprises to cultivate talents. Synergy can be a variety of forms, such as with software enterprises can joint training of software talents, and network equipment enterprises cooperation to build professional, enhance cooperation and training company professional skills, and systems integration companies talent post practice... In the practical operation of enterprise cooperation, we are faced with the following key issues.

\section{A. schools and businesses need to have a common vision.}

School enterprise cooperation must form a mutual benefit and win-win community; need to have a common vision. Local undergraduate colleges have their own unique culture and values, a certain academic freedom and traditional, strong public welfare, and the pursuit of profit, the enterprise organization has a strong utilitarian, market. The two kinds of organization's culture and the value idea are different, the starting point and the purpose are different, must promote the school enterprise cooperation, and must promote the culture and the value idea fusion. Which requires local undergraduate colleges and universities change idea, break through the pure academic value system, the positioning of teaching and scientific research to serve the local economy and cultivate applied talents, the enterprises to absorb some of the cultural value, seek common ground while reserving differences, the pursuit of common development; in addition, it is necessary for enterprise in the process of cooperation, to avoid excessive pursuit of short-term interests, to learn tolerance higher school academic exploration free characteristics, so that through the efforts of both sides, forming the consensus of applied talents training.. 


\section{B. to improve the system of school enterprise cooperation.}

To establish a long-term and stable cooperation between enterprises needs a sound institutional environment, the only system can be incorporated into the interests of enterprises and schools, the government. A sound system can promote the rapid and orderly development of school enterprise cooperation. One is to support the government's macro policies and regulations in the process of improving the cooperation between enterprises and enterprises in the process of improving the cooperation between enterprises and enterprises in the process of improving the cooperation between enterprises and colleges. Three is the system of the cooperative operation of enterprises. $^{[3]}$

\section{C. interests demand is the driving force of cooperation.}

School enterprise cooperation must be built on the basis of the needs of multi interests, mutual benefit and win-win. The main driving force for the implementation of enterprise cooperation in local undergraduate colleges is the need to get development funds and maintain the advantage of discipline development. Therefore, on the one hand, the local government should promote the cooperation between enterprises and local colleges and universities. On the other hand, enterprises should increase investment in science and technology, and the local government should strengthen the cooperation between local governments and universities. Secondly, the local universities should provide basic services to the personnel training and scientific research.

\section{D. government role is the driving force to promote the cooperation between enterprises and enterprises.}

University enterprise cooperation, local government must study the local economic development needs to promote the strategic industry, key projects, etc., standing in the height of the regional development, investment funds, formulate policies, and promote cooperation between colleges and enterprises, and promote the development of strategic industries, improve the scientific research ability of strategic industry and enterprise market competitiveness. In the process of cooperation between enterprises and enterprises, the government also needs to set up organizations of colleges and universities, enterprises, and constantly improve cooperation mechanism, rights and obligations, rewards and punishment mechanism, power mechanism, the government needs to act as a suitable mediation role in the face of disputes and contradictions between enterprises.

\section{TRAINING MODE}

In order to develop the research and applied talents as the main goal, the scientific research ability is an important index to evaluate these " 985 " " 211 " colleges and universities. And local undergraduate colleges and universities to cultivate applied talents, scientific research is the main service of local economy; the evaluation of local undergraduate colleges and universities is an important indicator of the degree of recognition of the enterprise.

\section{A. Market oriented reform teaching plan}

School enterprise cooperation in the computer class of professional personnel training, market oriented, schools and enterprises to amend the teaching plan. Specific school enterprise cooperation curriculum model as shown in figure 1. First year, the completion of a basic course learning tasks, to promote public class lectures, self-study, open book examination, required to complete the credits within four years; the second and third year, mainly for professional courses, launched professional course learning module, finished with a door in a theoretical examination, $3 \sim 4$ weeks of enterprise training each semester arrangement, module for the professional learning training project. According to the actual situation of enterprises, adjust the training time and personnel arrangement; fourth school year, complete the graduation design.

The school enterprise cooperation curriculum training mode is a professional core skills as the guide, the university will need to complete the core skills training for four years in the course of theoretical teaching, through corporate training, to complete the core skills. Professional core skill curriculum is set up by the school and the enterprise to develop the professional personnel training program for the blueprint, and jointly develop the core skills training, and arrange the double tutor, the implementation of the practical skills assessment, improve students hands-on ability.

\section{B. Classified and graded teaching}

For the computer professional students learning interest, hobbies, student achievement, learning ability difference, follow the principle of "teaching students in accordance with their aptitude, moderate, we organize students graded hierarchical teaching.

In the first academic year of the University, based on the course of the study, regardless of the professional, each year after the end of the professional choice. The students' learning ability, hobbies, professional direction of the subdivision, the students were classified and graded teaching, gradually forming a learning group.

Stratified teaching mode of classification is based on the concept of "let every student to develop" education, put forward the principle of "teaching students in accordance with their aptitude" the effective teaching methods. In the premise of the students to fully understand the premise of targeted teaching, and organize the appropriate skills training, skills assessment. Classification and classification of different teaching is conducive to the teacher according to the students learning situation and decided to learn the difficulty of training, and gradually form a competitive learning situation.

\section{Cooperation with enterprises}

For students' practical ability and the ability to program design, we combined with the enterprise development and application of video sharing courses, MOOCs courses, application design training platform, and gradually open up the virtual experiment platform, laboratory, and gradually promote the students' practice ability training, forming a training system for enterprise needs. 
We also encourage and support enterprises to invest in school training equipment, to develop a talent training program, signed a cooperation agreement to regulate the rights and interests sharing mechanism, so that enterprises in the cooperation of profitable, some people can use, can be known to. Support enterprises bigger and stronger, for the development of enterprises to do a good job of personnel reserves.

In order to encourage students to innovate, we have set up a scholarship to support students in all directions. To encourage students to actively participate in the research project of teachers, the attendant learning, improve detection of problems, problem solving ability, and gradually develop creativity and scientific research ability. Encourage students to participate in various competitions, guide students into the laboratory, to participate in the actual project exercise capacity. Combined with the research project of teachers and college students, let the students from the actual project "do the middle school, learn to do", and gradually the students learning mode from passive acceptance to explore the mode of [5].

\section{Reform assessment model}

Application oriented Undergraduate Colleges and universities graduate employment more than one line production, development, engineering services, management, technology, etc., can't meet the requirements of the market, is a graduate of qualified or not the final inspection standards. Employment oriented training mode of applied talents, need to be the market as a final judge of the talent test. To this end, we reform the student assessment model; increase the proportion of practical skills scores in the course assessment, and to develop skills assessment for the operation skills. At the same time, the school actively cooperates with the enterprise, hire enterprise high skill talents to work together as skills assessment.

\section{CONCLUSION}

With the market as the guidance, strengthen the cooperation between schools and enterprises in order to continue to promote the cultivation of applied talents. We actively promote the students to participate in the core skills training, build a complete set of technical skills training system, the integration of higher education, vocational education and continuing education, training of technical skills in the market recognition.

\section{ACKNOWLEDGMENT}

This research has been supported by Guangdong province college students practice teaching base construction project (Shaoguan University - Changsha lan-hu education science and technology compound talents practice teaching base ;teaching reform project of Shaoguan University (Project No. SYJY20141506), teaching reform project of Guangdong province in 2015 (Project No.560), and teaching quality engineering project of Shaoguan University and Guangdong province; Guangdong province collaborative education platform project, Guangdong Province pilot school project, Guangdong province education reform research project, Guangdong Province Higher School "professional comprehensive reform pilot project" ([2013]113), ).

\section{REFERENCES}

[1] Qin Zhentao, Yuan Jimin, Qi Shi Feng, et al. Study on Computer Education Teaching Forum [J]. local colleges and professional personnel training,2012(12):212-213.

[2] Wang Lingfen, Li Xizuo, Song Haiyu. The design of [J]. computer education in Computer Science in general colleges and Universities,2009(7): 64-65.

[3] Yang . The exploration and practice of the training mode of software talents training mode of engineering education ,type of science[J].,2013(12):35-36.

[4] Xiong Xiaobo, students of computer science and technology professional students' innovative ability to explore the $[\mathrm{J}]$. computer optical disc software and Application, 2012(7):77-78.

[5] Huang Chengbing. Research on the training mode of innovative network engineering talents in Colleges and universities [J]. Journal of Heilongjiang Institute of Education,2012, 31(5):101-107. 